concomitant fall in net protein in very young fruits in which active cell-division is taking place. Afterwards, in fruit of all ages, when a climacteric rise in respiration occurs, it is accompanied by a net increase in protein. It is argued that the climacteric rise in respiration is a result of increase in the level of protein which will be expected to reduce the adenosine triphosphate/diphosphate ratio. Over the climacteric period, although rate of respiration and net protein content both rise, the former rises more rapidly than the latter and, afterwards, falls at a faster rate than the protein content. It is suggested that this may be due to the 'new' protein containing a higher proportion of enzyme(s) directly involved in respiration and leading, for example, to a reduction in the adenosine triphosphate/diphosphate ratio.

\section{Ophioglossum: Organization in Embryos and Induced} Buds Compared

WHEN the sequence and rate of organ formation in embryos and induced buds of Ophioglossum vulgatum are compared, some interesting results emerge (C. W. Wardlaw, Ann. Bot., 18, 72, 397 ; 1954). In the embryo, the appearance of the primary root considerably precedes the organization of the shoot apex and the formation of the first leaf; but in induced root and shoot buds the reverse is the case. With the limited nutrition provided by the saprophytic underground prothallus, the first leaf of the embryo (actually the second leaf formed) does not appear above ground until after seven to eight years; but in buds induced in decapitated shoots, four to six new leaves may be formed in five to six months. Completely defoliated shoots may show a comparable rate of leaf formation. The conclusion is reached that while the fundamental pattern of development is the same in embryos and buds, the actual sequence in which the primary organs are formed, and their rate of formation and development, are referable to nutritional factors.

\section{Zoological Nomenclature}

As from June 30, 1955, the International Commission on Zoological Nomenclature will start to vote on the following cases involving the possible use of the plenary powers for the purpose specified against each entry. Full particulars were published on December 30, 1954, in Parts 10 and 11 of Vol. 9 of the Bulletin of Zoological Nomenclature. (1) Dama Frisch, 1775 (Cl. Mammalia), validation of, for use for the name for the fallow deer of Europe; (2) Helicella Férussac, 1821 (Cl. Gastropoda), validation of ; (3) rufa Linnæus, 1761 (Formica), validation of, and designation as type species of Formica Linnæus, 1758 (Cl. Insecta, Order Hymenoptera) ; (4) Carinifex Binney, 1865 (Cl. Gastropoda), validation of ; (5) Discias Rathbun, 1902, Upogebia Leach, 1814, Processa Leach, 1815, Xanthinae Dana, 1851, Upogebiinae Borradaile, 1903, and Processidae Ortmann, 1896 (Cl. Crustacea, Order Decapoda), validation of. Comments on these cases should be sent as soon as possible to Francis Hemming, secretary to the Commission, 28 Park Village East, Regent's Park, London, N.W.1.

\section{Group Discussion}

Over recent years the Central Council for Health Education (Tavistock House, Tavistock Square, London, W.C.1) has published a number of articles in its quarterly journal dealing with various aspects of group discussion in educational, social and working life. These evolked considerable interest and, as a result, the Council has brought them together and published them in book form. They include accounts of the theory and practice of group discussion by Dr. M. L. Johnson, preparation for a group discussion by Dr. Emrys Davies, the technique of running discussion groups by M. Fassam, how to run meetings by J. J. Gillespie and Dr. J. Burton, discussion in a secondary school by Frank Tyrer, the Quaker group by B. Pollard, and group psychotherapy by Dr. E. J. Anthony. There is also a detailed and comprehensive bibliography.

\section{Economic Developments in Mexico}

THE main article in the autumn issue of Progress, the magazine of Unilever, Ltd., describes economic developments in Mexico. It has been contributed by Dr. Eduordo Villasenor, formerly director-general of the Bank of Mexico, who shows that, despite all the difficulties thrown up by the geography of the country, agrarian reform and industrialization are increasing rapidly and are being accompanied by many developments in education and welfare services. Mexicans are particularly proud that their State University, which is the oldest on the American continent, now possesses the "most modern buildings and equipment of any university in the world".

\section{Documentation in Aeronautics}

AT the fourth meeting of the Documentation Committee of the Advisory Group for Aeronautical Research and Development of the North Atlantic Treaty Organization in Paris during November 2-6, closer liaison was recommended between the documentation committee and the technical panels of the Group, and in particular it was suggested that the committee might assist the panels in the preparation of bibliographies. Progress was reported in the preparation of the interlingual aeronautical dictionary. A French version of the British Standards Institution's glossary of aeronautical terms was ready for circulation for criticism; a German translation would be ready for revision shortly; Part 1 of a Dutch translation was ready for circulation; and Part 1 of a Russian translation had been revised. It was agreed to produce first individual volumes for each language, with an alphabetical index, for limited circulation in the country concerned for criticism; and not to undertake the preparation of the complete dictionary until eriticisms had been received and amendments made. It was also agreed to maintain contact with Dr. Heflin's project for a dictionary of Air Force language.

A sub-committee was appointed to review critically the production of an international abstract bulletin and, if possible, to recommend an alternative approach to the improvement of abstracting services. Subject classification schemes used in aeronautics were also discussed as well as methods of retrieving punched cards, and it was recommended that, in co-operation with Unesco, a list of systems, covering the mechanics as well as methods of coding, now in use in aeronautical fields should be made. Recommendations made at the previous meeting in favour of improving the availability of classified reports were confirmed and a suggestion for the preparation of a guide to the sources of aeronautical information was welcomed. It was also agreed that the adequacy of the translation coverage of aeronautical literature requires close examination, and a draft report is to be prepared for tbe next meeting. 